\title{
Exploring Creativity in Social Studies Education for Elementary Grades: Teachers' Opinions and Interpretations
}

\author{
Sukran Ucus ${ }^{1}$ \\ ${ }^{1}$ School of Education, Ahi Evran University, Kırşehir, Turkey \\ Correspondence: Sukran Ucus, School of Education, Ahi Evran University, Kirsehir, Turkey. E-mail: \\ sukranucus@gmail.com
}

Received: December 1, 2017

Accepted: December 19, 2017 Online Published: December 21, 2017

doi:10.5539/jel.v7n2p111

URL: http://doi.org/10.5539/jel.v7n2p111

\begin{abstract}
Creativity is the critical point to developing innovative and effective citizens and children in learning social studies. The purpose of this study is to explore how creativity is promoted in social studies classrooms for young children and to research teachers' opinions and interpretations of creativity in Turkish elementary schools. The study was conducted with in-depth interviews, teacher observation, and teacher drawings. The participants included 33 Grade -1 to Grade 4 (K1-K4) teachers, all of whom taught "life science" which is a key and preliminary subject for social studies from Grade 1 to Grade 3, and social studies for Grade 4 in central Turkey. The case study was used as a qualitative methodology. The data was analyzed using MAXQDA-11. The findings revealed that teachers were highly motivated and eager to nurture creativity in their students' social studies learning in their implication for practice. They also indicated some obstacles regarding low-quality curriculum and instruction, teachers' negative perceptions in promoting creativity, and finally a lack of teacher flexibility, freedom, and well-qualified professional development.
\end{abstract}

Keywords: social studies, creative thinking, creativity, elementary school teachers

\section{Introduction}

The most effective paradigm for integrating the social domain of knowledge and skills is through children's personal experiences at home, at school, and in the broader community in which they live. Social studies are one of the essential aspects of children's development and education, including social skills, socialization, and social responsibility. It is based on children exploring people's interactions in and with their social and physical environments, now and in the past (Kostelnik, Soderman, \& Whiren, 2011). It is also essential for a democratic society, which depends on citizenship, encompassing the adoption of democratic values, the scaffolding of information, and adding the richness to people's lives for the country and humanity. Also, social studies are the study of human beings in their environment and of the concepts, skills, and attitudes which are constructed for them to become social beings and to understand the complex world (Mayesky, 2009, p. 514). The social studies include an extensive a broad array of topics which are drawn from theoretical ideas from anthropology, sociology, history, political science, geography, economics, and psychology. For young children, these themes are explored through playing, personal interactions, literacy and project-based learning, collection and analysis of data, and report presentation beginning with the study of self, family, and community. These themes are expanded to comprise local and national history, economics, political science, and geography in the primary grades to provide meaningful content that helps prepare them as lifelong learners (Lackaff \&Mindes, 2013). Major components of dynamic social studies are based on respecting diversity, functional content, process skills, intrinsic motivation, and cross-curricular integration to function as young "social scientists" (Maxim, 1999).

In Turkey, social studies are also called "Life Science" from grade-1 to grade-3 in Turkey as an integrated and holistic course. It draws from social, social-cultural and economic education, biology, citizenship education, history, geography, nature, values, health, and safety at home and in society (Uçuş et al., 2017). Life science formulates the basis for future courses, specifically social studies, and for the relations and behaviors of people in the society to adopt and prepare for the future. Student-based learning, active participation in the learning-teaching process, learning by doing, and scaffolding knowledge by students are standard features in the context of the constructive approach to life science education. The main knowledge and skills in the curricula 
must overlap with students' needs and develop the child's mental skills and personality at all points in the lessons (Kabapınar, 2007).

The National Council for Social Studies (NCSS) grouped social studies content as follows: Kindergarten addresses awareness of self in the social setting, first grade addresses the individual in school and family life, second grade addresses the neighborhood, third-grade addresses sharing the earth with others in the community. The NCSS organized social studies content into 10 themes for the upper grades such as culture; time continuity and change; people, places, and environments; individual development and identity; individuals, groups, and institutions; power, authority, and governance; production, distribution, and consumption; science, technology, and society; global connections; and civic ideals and practices (Mindes, 2008; Parker, 2012; Wallace, 2005). When comparing them with social studies for elementary grades with the US, themes from kindergarten grade to grade 3rd from the US are equal to units so that curricula have followed a unit-based approach since 2015, for 1st grade to 4th grade (MONE, 2017a, 2017b). Respectively, the life science units are called "life at school," "life at home," "healthy life," "secure life," "life in our country," and "life in nature" in Turkey. The elementary social studies units include: "individual and society", "culture and heritage", "people, places, and environments", "production, distribution, and consumption", "science, technology, and society", "effective citizens", and "global relations" (MONE, 2017a, 2017b).

Social studies classes not only help prepare children with competencies in the "three Rs" but, to help students become active citizens, they must also give them the knowledge, skills, and civic virtues necessary to become active participants in the world of the 21st century (Maxim, 1999). There are three categories of 21st skills such as learning and innovation skills (creativity and innovation, critical thinking, communication and collaboration), information, media and technology skills (information literacy, media literacy, knowledge, communication and technology ICT literacy), life and career skills (flexibility, adaptability, initiative and self direction, social and cross-cultural skills, productivity and accountability, and leadership and responsibility) (Zarillo, 2012). When it comes to skills of creativity, underlying 21 st-century skills include thinking creatively, working creatively with others, and implementing innovations (Piirto, 2011).

The National Advisory Committee on Creative and Cultural Education defined creativity is an imaginative activity fashioned to build outcomes that are original and of value. It has a significant impact on children's holistic development, such as social, personal, and intellectual, by benefiting the students' preparation for the future. Creativity is possible in cultivating and boosting as a human activity in all areas, and it draws from all areas of human intelligence (Loveless, 2015). Creativity allows children to gain the skills indicated by the Qualifications and Curriculum Authority (QCA) such as questioning and challenging, making connections, seeing relationships, envisaging what might be, exploring ideas, keeping options open, and reflecting critically on ideas, actions, outcomes (Craft, 2003, 2014; Loveless, 2015). Creativity encourages students to engage more fully in the learning process and to discover additional meanings in their work, which results in lengthened memory of knowledge in the classroom environment (Kirkendall, \& Krishen, 2016).

Citizenship is related to creativity and is fundamental, whether at the radical or the conservative end of the continuum or at points. Participative, active citizens of all political persuasions will need the ability to solve problems and consider creative solutions in society. It is also a requirement for a free democratic society (Woolley \& Claire, 2015). Geography and history are also particularly interesting starting points for creative teaching and learning because the teacher has clear and immediate openings through which the child can be engaged (Jones \& Dennis, 2004, p. 82). A recent project found that: "Young peoples' creativity seems to flourish when their learning environment values diversity, encourages them to experiment and take risks and offers trusted guidance, respect, and support" (Jones \& Dennis, 2004). Creative, democratic and empowering teachers who are committed to developing creative citizens for the future create a classroom climate in which children experience democracy first-hand. They could see possibilities for developing children's ability to engage with the present and the future, know how to develop an ethos of collaboration and trust, which are both essential because of the risks and dynamics of thinking creatively, and know how to set up opportunities for creative thinking about society, whether "blue skies" thinking or pragmatic (Melendez, Beck, \& Fletcher, 2000; Woolley \& Claire, 2015).

The social studies curriculum complements the developmental process in several ways. Firstly, it promotes the development of social knowledge which will help children to understand the world and current ideas (physical and socio-conventional knowledge-cognitive development). Secondly, it opens doors to learning about oneself and others (social and emotional development). Third, it promotes appreciation of the individual's creative and expressive abilities (creativity and cognitive development). Fourth, it involves children in direct experiences (physical and motor development) (Melendez, Beck, \& Fletcher, 2000). 
The input of teacher and the school environment constitute the contextual and cultural factors affecting young children's creativity. However, they don't look into biological, personality and cognitive factors although these variables of individual differences are also antecedent variables of young children's creativity. Teachers have a crucial role in establishing a classroom context facilitative to creativity education (Chien \& Hui, 2010). The teacher's role is to promote discovery, suggest next steps, set the stage, facilitate, model, trust, accept child mistakes, treat children with dignity, instruct, manage, observe, evaluate, reflect and plan. This role requires content knowledge along with regular reflection upon practice, plus flexibility and creativity. The teacher who knows the learners in the classroom provides diversified learning opportunities for the particular children. Teaching and learning are thus inquiry-based and built on the curiosity of the learners (Mindes, 2008).

Inspired by the constructivist education approach, life science and social studies curricula were first updated and developed in 2005 and secondly updated in 2009. Reflections from the curricula developed in 2005 and in 2009 were emphasized creative thinking skills (Kabapınar, 2007; Tay \& Baş, 2015; Uçuş Güldalı, \& Demirbaş, 2017) with phases and behaviors such as originality and being unique, developing new ideas and the imagination, establishing extreme and unique connections, using emotions, instincts, and passion actively, taking risks, having courage, and facing challenges (Kabapınar, 2007). However, creative thinking skills were officially removed from the curriculum guidelines in 2015 and 2017 (MONE, 2017a, 2017b; Tay \& Baş, 2015). Moreover, the current study's topic is limited with few previous studies in Turkish social studies education (Kutanoğlu, 2014; Uçuş Güldalı \& Demirbaş, 2017; Uğraş, 2011; Vural, 2008). Thus, there is a research gap regarding the extent of the implementations and practice of creativity on social studies classes and how teachers promote children's creativity in their classrooms, through research on teachers' cases in a triangulation method.

\subsection{Purpose of the Study}

The purpose of this study was to explore how creativity is promoted in social studies classrooms for young children, to research teachers' beliefs on creativity, and to interpret creativity in the learning of social studies for young children in Turkish elementary schools. More specifically, the questions are explored as follows: (1) How do teachers understand and define creativity in a social studies classroom? (2) How do teachers support creativity in a social studies classroom in the context of elementary education? (3) What factors (support and obstacles) affect teachers' ability to foster children's creative thinking for social studies in elementary education? Also, how do these factors influence the way design thinking is used in classroom learning? and (4) What images do teachers produce when representing creativity for social studies in elementary education?

\section{Methodology}

Qualitative case study research methodology was used as the most appropriate methodology, about the purpose of the study. In a holistic and intensive approach, case studies are used to obtain a deep understanding of a phenomenon and obtain detailed and in-depth information on several cases, and the research questions are based on "how" and "why." They provide an exact description of a real situation by means of presenting the opinions of individual participants directly and collecting the data through comprehensive and in-depth methods (Creswell, 2015; Yıldırım \& Şimşek, 2008). Questions are based on "how people interpret their experiences, how they construct their worlds, and what meaning they attribute to their experiences" (Merriam, 2009, p. 5). The current case study was conducted to explore teachers' opinions, beliefs, and experiences through interviews, classroom observation, and teachers' drawings by themselves to reveal perceptions and opinions about creativity in social studies education as a phenomenon.

\subsection{The Participants}

A combination of convenience and purposeful sampling is used to include participants reflecting an unusual and maximum variation in a researched case (Creswell, 2015). A convenience sampling technique emerged here based on availability, and fast and easy access in this study. The participants in this study were 33 teachers from three public schools who taught K1-K4 (from grade 1 to grade 4). Two teachers were male, and the rest were female, which is representative of K1-K4 in general. Five of them taught Grade 4. The rest of them were equally divided into each grade. The three primary purpose sampling criteria included teacher participants; teaching for grade 1 to grade 4 (K1-K4), and teaching social studies. A total of 33 elementary school teachers voluntarily agreed to participate in this study.

\subsection{Data Collection}

The data of the study were collected primarily from interviews, and teacher observations and teacher drawings as secondary data. The interviews were audiotaped and transcribed verbatim by the researcher. Next, teachers were observed in social studies classes which took approximately between 20 minutes and 40 minutes for the 
researcher to have a deeper understanding. Teachers were also asked to produce a drawing to represent the aspect of creativity for students in the learning of social studies. After that, teachers were asked to explain their drawings with prompting and divergent questions such as "How? Why?", to explain more. Their verbal statements and explanations were also tape-recorded and transcribed. These were combined with the data of the interviews for comparison and to enrich the data. Participants were named and coded with their initial letters of name or surname as "Miss A, Mr. B".

\subsection{Data Analysis}

MAXQDA (11.0) was used for data coding and analysis. Three parts of the data were combined and analyzed to identify main themes which were used to support the enrichment and verification of data. The data was analyzed at three levels such as teachers' individual cases and experiences, comparisons of cases and experiences, a comparison across the case studies respectively. Besides, an inductive qualitative analysis was used to consider the data in the broader and horizontal perspective and descriptive analysis, which are interpreted by defining and generating themes (Creswell, 2015; Merriam, 2009; Yıldırım \& Şimşek, 2008). The main themes and related concepts emerged more distinctly, and relevant literature was referred to further clarify and integrate with the analysis that has developed. Coding was conducted after each interview to inform the following interview. Similarities and differences were identified in the codes of existing categories. Codes were classified in their emergent categories which were explored for interpretation and understanding. In the current study, teachers' interviews, classroom observations, and teachers' drawings were used as data collection tools to triangulate data sources, and by converging three sources of data obtained from teachers, this provides comprehensive and coherent justification (Creswell, 2015). Moreover, the researcher used member checking and peer review (Creswell, 2015; Merriam, 2009). In member checking, the researcher shared the analysis of the data with all the teachers who participated in this study. Thus, teachers rethought their interpretations. In peer review, feedback from academics in the field of experts in social studies education and elementary education was received and combined for the analysis of data.

\section{Findings}

The current study's findings were based on the themes that emerged from the teacher interviews, teacher observations in the classroom, and images of creativity in teaching and learning for young children in social studies education. They can be described in six different ways: 1) Definition of Creativity for Social Studies Class, 2) Implications for Practice in Social Studies Classroom to Promote Creativity, 3) Considerations and Factors for Social Studies, 4) Teachers' Suggestions for Nurturing Creativity in Social Studies Education Entailing Elementary Grades, 5) Behaviors and Characteristics of Teachers, 6) Teachers' Images of Creativity in Social Studies Education

\subsection{Definition of the Creativity for Social Studies Class}

All of the 33 teacher participants $(100 \%)$ stated the significance of creativity for students to have deeper knowledge and better social studies outcomes.

Many of them (25) emphasized the unique solutions and ideas for the quantity of strategies students might generate. These teachers identified creativity in social studies through problems in social life and events, having various perspectives for the society to be an active future citizen, conflicts, dilemmas for thinking divergently, and creating innovation for the community and social life.

For example, Mrs. D and Mr. B,

"Creativity of social studies for elementary grades includes multiple ways of solving a social problem and thinking of a variety of strategies or approaching a problem from various perspectives."

"Creativity is a necessity for social studies. We need to figure out daily life problems in an unusual way. Creativity for social studies is to find an unusual thing to develop the society."

\subsection{Implications for Practice in a Social Studies Classroom to Promote Creativity}

Based on the teacher interviews, the approaches and strategies they use to promote creativity in social studies education in young children fell into six themes: 1) Comprehensive educational environment: curriculum, tools, and materials, psychical and social condition; 2) enriching perspectives and experiences; 3) project-based learning environment; 4) interdisciplinary teaching and learning for supporting the social domain, 5) interactive teaching-learning strategies, and 6) a nurturing environment with freedom of thought and speech in the classroom, and encouragement in multiple ways.

11 teachers focused on expressing and communicating ideas. They pointed out students' expressing their social 
studies process and the ability to explain the thinking process. Many of them (27) emphasized the quantity of interactive and differentiated teaching-learning strategies, for example, Mr. D emphasized drama, game-based learning, problem-solving creative literacy foster students' social thinking skills. Mrs. B. indicated the interdisciplinarity of social studies.

"Integration of the arts or economy to social studies creates opportunities to facilitate creative expressions for young children. Thus different disciplines enrich students' cognitive minds."

A few teachers (12) discussed the association between the curriculum and components of creativity. Mrs. Sm stated that "If the philosophy, skills, objectives of curriculum do not overlap with the nature of creativity, nothing changed. As a result, it's all talk no action. After the revision of curriculum 2005, there was a core skill called "creative thinking." There were implementations of objectives and content. We're currently implementing the curriculum updated in 2015 and 2017. When I compare all of them, curricula from 2005 and 2009 are more advanced than the new ones.The superficial content of the curriculum does not promote creative thinking for children. The new curriculum did not support students to achieve deep understanding."

Twenty-four teachers emphasized the role of the environment in promoting creativity in social studies education. A comprehensive educational environment was described concerning creativity in curriculum, tools, materials, and physical and social condition. The teachers also discussed the significance of a resource-rich environment. They particularly noted how the students interact with and are influenced by the environment in the learning process.

Some of the teachers (9) talked mostly about the diversity of learning tools and materials in the classroom as well as content and structure. For example, Mrs. A commented on the preferences of different materials to stimulate and enrich students' creative ability.

\subsection{Considerations and Factors Effecting for Social Studies}

Teachers explained what considerations and factors were for creative education and their answers were identified as falling within six themes: peer, teacher, parents, curriculum, source, school. They emphasized these factors were changeable and manipulative. If they are taken into consideration and given importance, creativity could be improved. If not, they will not be beneficial and practical.

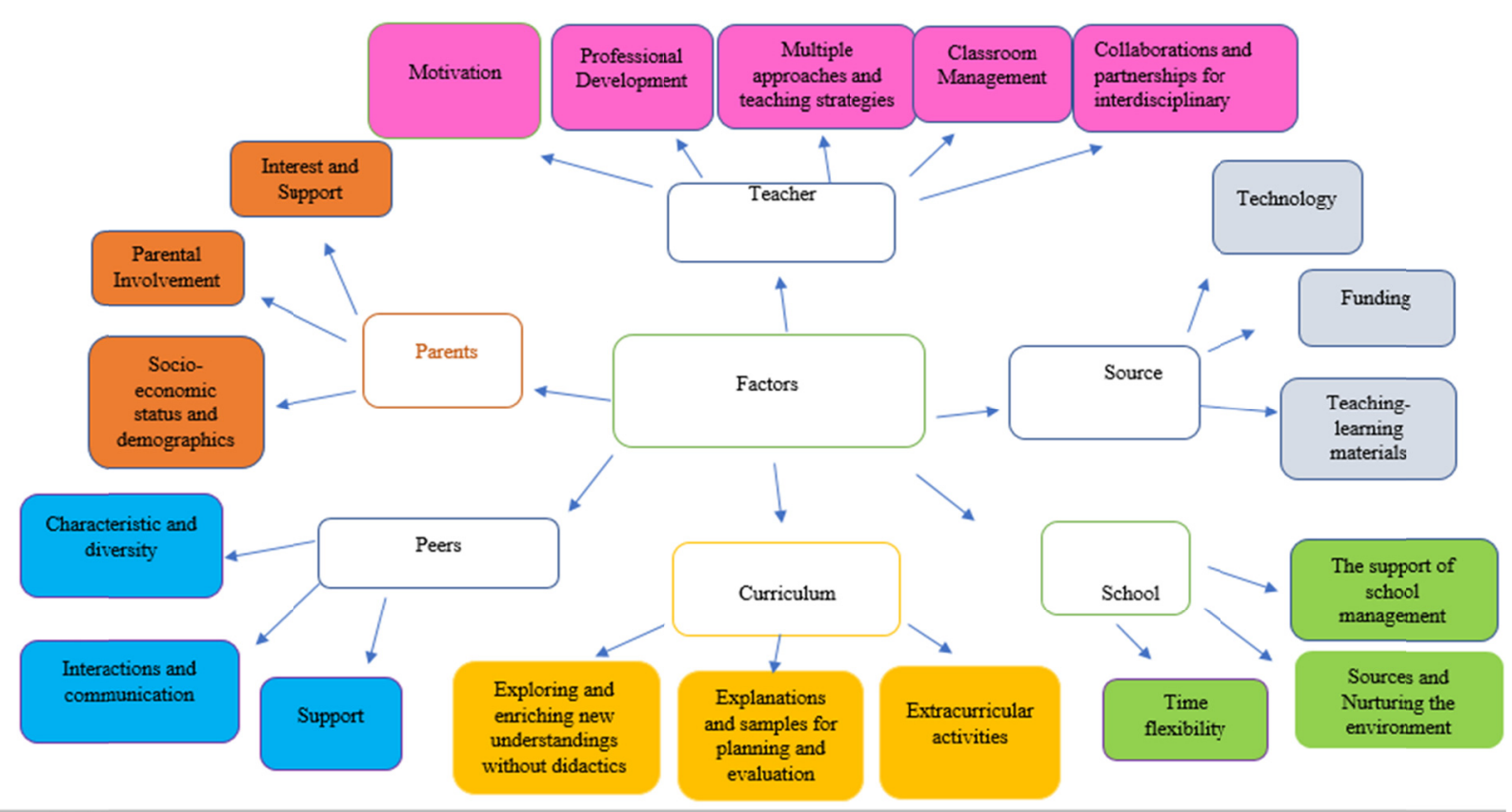

Figure 1. Considerations and factors affecting social studies

Figure 1 shows six themes and their sub-themes about the factors and considerations affecting social studies. According to teachers' explanations, curriculum refers exploring and enriching new understandings without didactics, explanations, and samples for planning and evaluation, extracurricular activities in terms of factors. 
The school addresses time flexibility, the support of school management, sources and nurturing the environment. The factors of peers include characteristic and diversity, support, interactions, and communication. When it comes to parents, parental involvement, interest and support, socio-economic status and demographics are sub-themes for this theme. When it comes to the theme of "teacher", it refers motivation, professional development, multiple approaches and teaching strategies, classroom management, collaborations and partnerships for interdisciplinary creativity. The lastly, the source is the critical factor. According to teachers' implications, technology, funding for the creative projects, teaching-learning materials are sub-themes which affect the creativity.

They (27) mostly defined these considerations and factors as obstacle and difficulties. The majority of teachers (26) mainly mentioned low-quality curriculum, lack of materials, lack of knowledge, inconvenient school environment, difficulties in interactive and creative teaching for young children, lack of resources especially technological applications, no parental involvement, and lack of undergraduate programs regarding creativity and implications of creativity in the classroom. Some of the teachers (12) indicated classroom management problems, difficulties with collaborating with teachers and school management or their colleagues. Some teacher statements are as below:

"I have some teaching issues. Teachers mostly focus on reading and writing for early grades. Math, also. Nurturing students' creative thinking is impossible. Even life science course is the last thing in the $1^{\text {st }}$-grade classroom. However, children actually need basic learning of social life events, science, geography, and history."

"I sometimes don't know how to manage instruction and peer interactions."

"Schools do not have enough implementations. Some high SES schools provide a different room with any supply teacher or special education teacher. Elementary school teachers cannot support their development."

"According to me, our classrooms are very crowded. We can only support the children's' academic skills, not creative or critical thinking skills. We only promote the improvement of the students' social reciprocal communication. It may be accepted as a preliminary action for freedom as the basis of creativity."

"Physical conditions and social studies curriculum do not overlap in terms of implementing some creative teaching-learning activities.”

"I have some limitations on implementing different activities. Planning and implementing creative activities take too much time in a general school day. We're not very flexible. We need to follow the instructions of the social studies curriculum."

\subsection{Teachers' Suggestions for Nurturing Creativity in Social Studies Education in Elementary Grades}

Teachers also pointed to the physical and social condition, psychological support, supportive teaching strategies, investigating learners' needs and interests, and flexibility, which were highlighted as sub-themes of their suggestions. They also mentioned different kinds of materials, the support from school management, family, sustainable parent-school partnership, psychological support, technology-based learning to promote creativity. Some parts of teacher statements are as below:

"Creativity could be improved for each child in the classroom regardless of academic competencies. Suggestions could be changed in terms of each child's needs, abilities and interest. Each child needs a different learning environment and condition."

"Teachers need knowledge and implications for practice such as creative, individualized and differentiated instruction."

"Social studies is based on verbal skills and content. There is a distinct definition of creativity in social studies. This definition must be included in strategies for particular content of social studies, and specific teacher behaviors. It must be a roadmap."

"Schools need to be re-designed psychically. Most of the schools do not have space available for creative education."

"Classroom management is a challenge while conducting interactive teaching. I have some concerns about doing some creative social studies activities. Thus, teachers need comprehensive professional development. How to foster students' creativity? How to protect my classroom management in the creative classroom? Teachers need to change their points of view. Besides that, there is the other challenge of the academic success based education system. It is a general issue for Turkey." 


\subsection{Behaviors and Characteristics of Teachers}

In this part, social studies classes and life science classes were observed regarding teacher behaviors. A majority of teachers depended on curriculum instructions, and they followed textbooks. Some of the teacher behaviors were supporting ideas, listening effectively, elaborating students' ideas, requiring alternative ways (plan a, plan b), having character and values (empathy, innovation), thinking characteristic (divergent, critical, reflective or typical thinking), being energetic, being flexible, being exciting, being sensitive, having awareness regarding life and events, asking open-minded questions, multiple approaches to gather social information and having intellectual expression to promote creativity. The small conversation was from the classroom as below:

Teacher: Tell me your favorite toy as a child. If you sold it in the market, what would the advertisement be like? Tell us about your marketing strategies... Make a story with these words/ concepts.

Teacher: e.g., great job, excellent, think unusually...If you were a prime minister, what would you do a unique project for children?

When it comes to negative behaviors against creative behaviors, judging students' ideas, not creating an opportunity by giving enough time for each student for their work, harsh criticism, discouragement, and not listening appropriately were observed.

The teacher didn't ask any question to the student about his artwork. She just looked at his work quickly, but she didn't say anything about it.

Teacher: e.g., that's a ridiculous idea, think more thoroughly and correctly, please.

On the one hand, teachers' positive behaviors were mostly based on using positive and warm words to promote student's motivation, discussion, and argumentation through fostering student's creative thinking. On the other hand, teachers have negative behaviors about using traditional teaching style, discouraging students' attempts, causing lack of students' motivation. Teachers (33) mostly relied on the content of life sciences and social science's textbooks.

\subsection{Creativity in Social Studies Education from Teachers' Imaginations}

Teachers were asked to explore their images regarding creativity in social studies education, and their mental images related to the creativity of social studies from several points of view. They drew from their imaginations such as "interrogation mark, eternity, a community in a rainbow, cultural combination in a colorful shirt, sky, nature or bazaar." After drawing, teachers explained why they drew that and what they wanted to point out. Their reasons for selecting the particular drawings of creativity in social studies varied based on many perspectives. They labeled their drawings in the following way, for example: Nurturing inspiration and imagination, a bridge to the life, being out of the class, surrounding students with different stimulations, creating conflict for society, social and environmental issues, integrating many cases into the classroom, Multiple tasks and divergent thinking, pretending to figure out issues of real-life events in the classroom environment, creative thinking as a lifeblood, to have high quality minds.

Some explanations of drawings were from teachers' imaginations like that: e.g., Interrogation Mark: to start a creative behavior with a highly qualified question, Turkish Leader Ataturk as a role model for innovative and creative characteristics and nature. Some samples from teacher imaginations are as below:

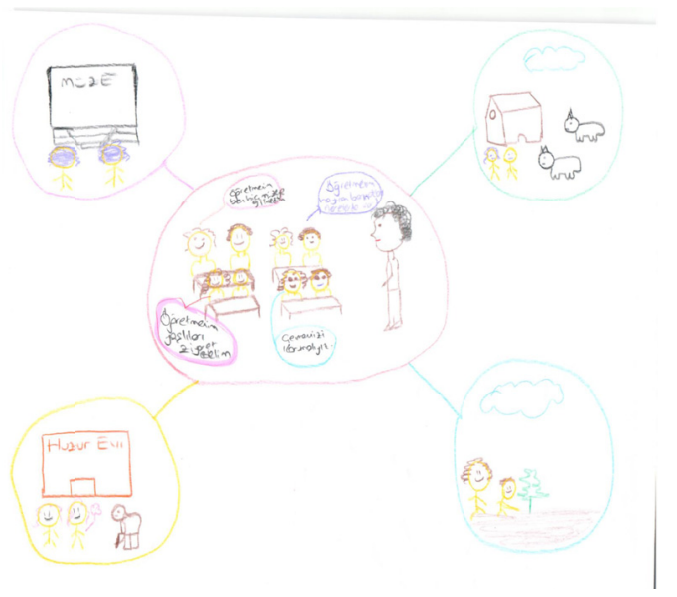

Images 1 . 
Images 1 illustrate learning and teaching environments which are available out of the class make pupils more active nurturing their creativity and thinking skills. Mr. C explained like that: "Social studies have based the life, events, and society. We cannot think it without different environments and stimulants. Museum, zoo, senior center, nursing care center, and nature may be a classroom for life science or social studies class."

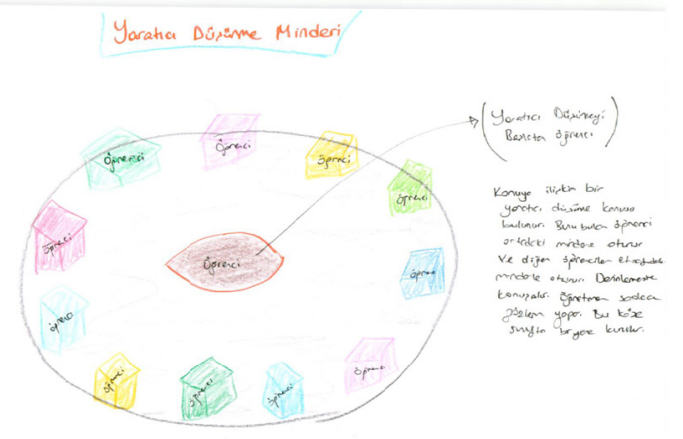

Images 2 .

Mrs. $\mathrm{C}$ drew creative thinking cushion in Images 2. Her explanations were like that: "One pupil is a leading to the process with a question or a conflict. The teacher is just only an observer in the classroom. Students develop their ideas in the course by inquiring, focusing on evidence."

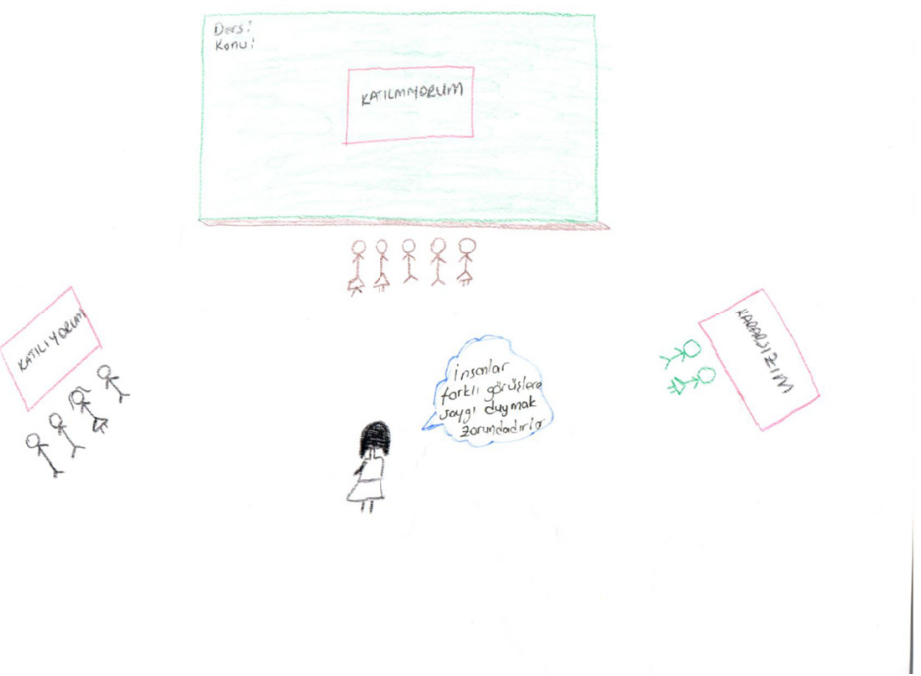

Images 3 .

Mrs. Se drew attention to developing ideas. She told the technique for producing and developing the idea "I agree because, I am not sure because ., I do not agree with that, because....."

She mentioned about this technique mostly used in her social studies class for the 3 rd grade. 


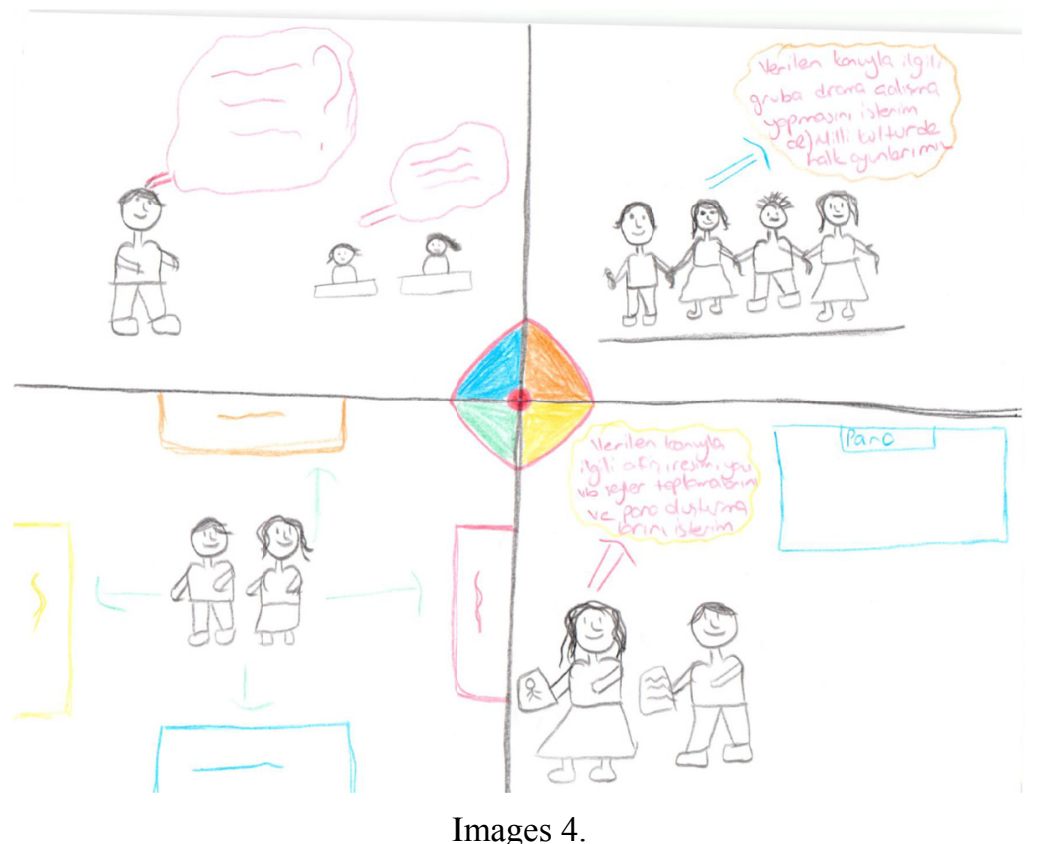

Miss Y stated constructing creativity may be possible focusing on multiple tasks and divergent thinking. According to her, this image illustrates corners which are drama, projects, preparing posters, combining different interests, abilities, and tasks.

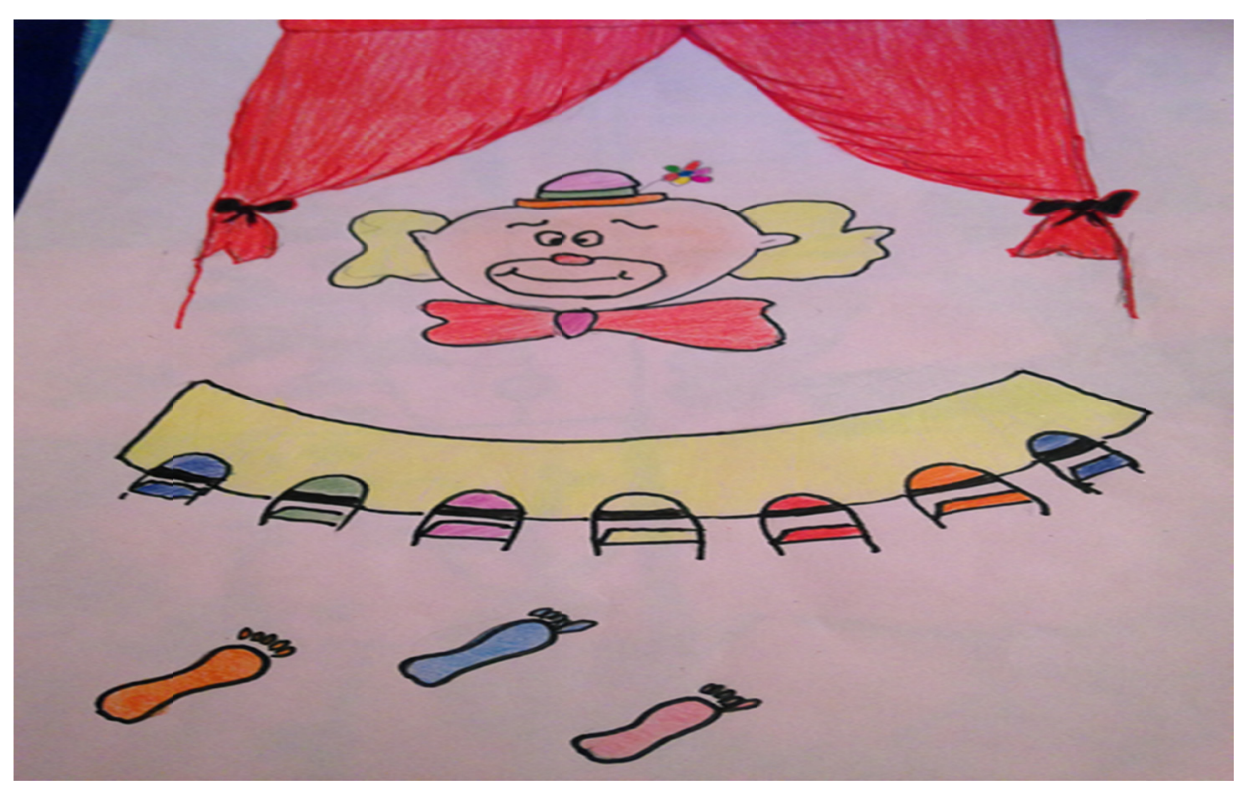

Images 5 .

Miss Ge mentioned about the environment in the context of existing positive climate for creativity. Out of the class, making the different environment, physical condition are principals to feel free and think creatively. This drawing may be accepted the sample of the interactive classroom as a symbol. 


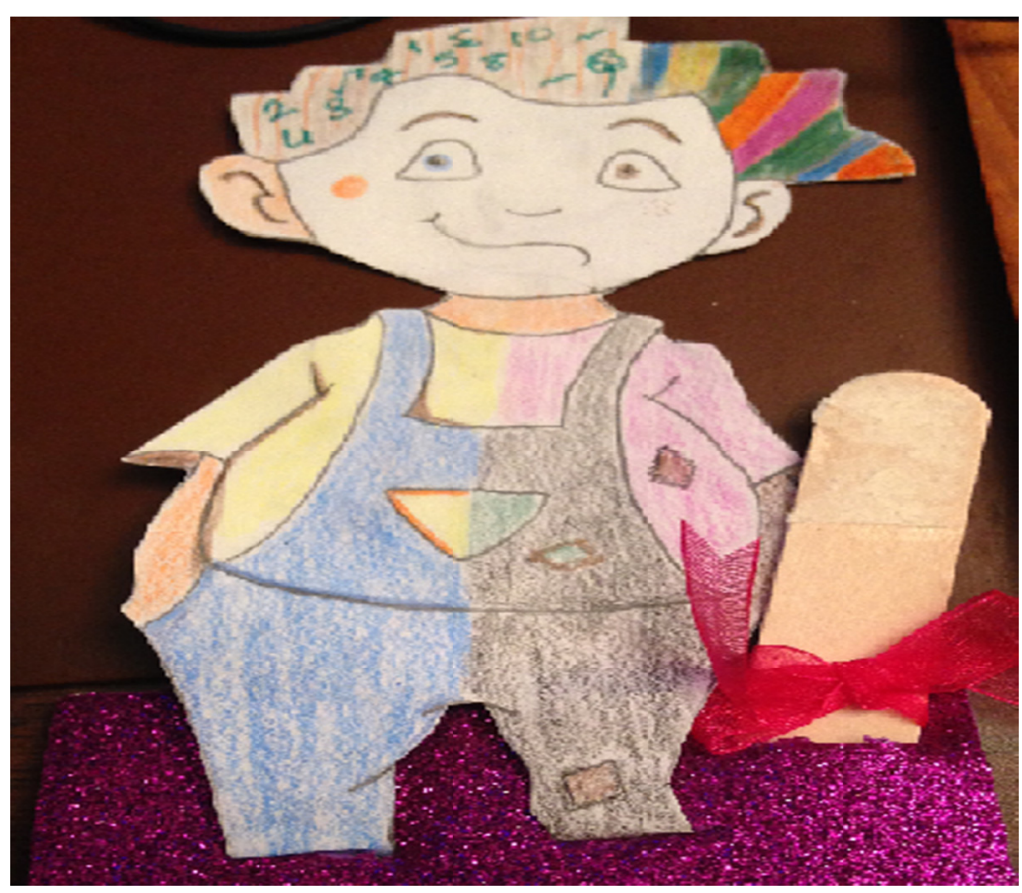

Images 6. Making conflict

Mrs. K drew Images 6 because of the explanation for the nature of social studies. She told about that making conflict was an encouragement for students to function as young "social scientists." She stated controversial issues, problems, and conflicts about the social issues cultivate students' imagination and curiosity. In general, the drawings were made an outline some principles basic requirements and principles for creativity in social studies education for young children such as the importance of physical environment, divergent thinking, nature-based areas, inspirations, and multidimensional learning-teaching process and constructs.

Overall, the teacher thought that creativity was a requirement and significant component by scaffolding children's divergent thinking skills and outcomes. The nature of social studies is convenient and eligible to cultivate the creativity based on their opinions. However, teachers have limitations and difficulties to use different materials and to nurture classroom environment and enrich the curriculum.

\section{Discussion}

The current study explored creativity in social studies education for elementary grades with teachers' opinions and interpretations. The findings described creativity and its reflection of the educational process from the viewpoints of teachers. Firstly, all of the teachers thought creativity was significant in social studies education, and they were highly eager to promote creative thinking for their students and represent creative teacher behaviors in social studies practices. A majority of teachers expressed that they had positive perspectives on activating all aspects of creativity in social studies classes because of the easy integration of the nature of social studies, which includes social life events, life skills, and the experience of daily life. Children explore social knowledge, concepts, and skills through daily interactions, routines, activities, and in the instructions of classroom functions. They scaffold their understanding of democracy, history, sociology, economics, and culture via their social encounters and activities (Kostelnik, Soderman, \& Whiren, 2011). Activities related to daily life skills are more effective in developing creativity (Yıldırım, 2010).

They perceived creativity as the ability to have divergent thinking in terms of social studies and the creation of unique solutions for social life events and the issues in society. They also indicated that components of social studies education (e.g. Social studies' materials, the curriculum, design of classroom) were not available and convenient for fostering students' creative thinking and did not respond to the need to activate creative thinking for all social studies tasks, even though they were able to use and promote creativity in social studies activities and practices. In alignment with some previous research, teachers endeavored to stimulate their creativity, as well as the role and place of students' creative activity at school. The teachers understood creativity as creative potential, as the ability to think independently and to give new and original solutions to all kinds of tasks and 
problems (Gralewski, 2016; Gralewski \& Karwowski, 2016). Secondly, when this finding is viewed in relation to teacher practices, teachers' views did not overlap with their implementations, and there were considerable differences among the two constructs. Similarly, Gralewski's (2016) research highlighted the gap between verbal support for developing students' creativity at school and classroom practice regarding creativity.

The constructivist approach has been applied since 2005 in Turkish education system, curricula, and aspects of teacher competence and implementations in Turkish education system. There have been three curriculum changes and updates in social studies education for elementary grades. However, when comparing curricula from 2009 and 2015, while the creative thinking skill and objectives related to creativity were observed in the social studies curriculum developed in 2009, any component of creative thinking skill has not been observed in the curriculum developed in 2015 (Tay \& Baş, 2015). Lack of creative thinking skills in the curriculum developed in 2015 is persisting (MONE, 2017a, 2017b). Similarly, a majority of teachers from the current study mentioned inadequacies, low quality, and poor content and learning objectives in the social studies curricula. There were no different views among teachers who teach either life science course or social studies course. There is a need for revising and rethinking creativity in the curricula in a comprehensive approach which comprises philosophy, general goals, main skills, approaches, and teaching-learning techniques, which have been indicated. Creative thinking is one of the main skills in the curriculum. Thus it is possible to help learners gain this skill with rich and multiple-task based content (Craft, 2003), as teachers stated in this study, with not only textbooks as an educational tool for content. This finding aligns with Kutanoğlu's research (2014). Elementary school teachers in Kutanoğlu's research (2014) stated that materials and tools were not sufficient to foster children's creative thinking in life science courses and teachers only prefer to use course textbooks as a tool. Rich content and goals can contribute to teaching creative thinking. Creative thinking studies based curricular research may provide broad understandings and interpretations of what creativity is and how to promote it (Bal, 2014; Kutanoğlu, 2014; Uçuş Güldalı \& Demirbaş, 2017; Uğraş, 2011).

Curriculum and instruction are two aspects of teachers' professional development that need to be reconsidered with regards to innovation and creativity in education (Faulkner et al., 2006). A previous study has shown that, in Taiwan, teachers' perceptions of creativity positively intensified in relation to curriculum design and teaching methods (Chien \& Hui, 2010), while other studies highlighted that teachers' wealth of experience and skills in curriculum adaptation and design might be significant assets for schools in general (Craft, 2003; Kampylis, \& Berki, 2014). A creative curriculum enriches children's knowledge about society through biographies, stories, and situations which challenge and stimulate their understandings of possible actions and ways of life in the world; It develops qualities and capabilities of empathy, creative problem-setting and problem-solving, and encourages higher order thinking skills (Woolley \& Claire, 2015). A functional and creative social studies curriculum includes rich activities from the arts and uses creative expression. In that sense, young children have a better understanding, by these experiences, of social concepts, historical events, and geographical abstractions. Including the arts in social studies, the curriculum provides opportunities to beneficially integrate three of the ten curricular strands, culture, individual development, and identity, and global connections, into the curriculum. The arts are an effective way for young children to work with abstract concepts. Learning about the arts is also an appealing and versatile way for children to learn about life. For example, the farm theme can be explored through music, dance, visual arts, theatre, and literature (Melendez, Beck, \& Fletcher, 2000).

Teachers mentioned that factors which have a great impact on creativity in social studies education may be manipulated either positively or negatively. They expressed that if those factors were integrated with positive perspectives and ways, creative teachers'/students' behaviors could be observed. If not, they could occur in the educational process as obstacles. Obstacles which teachers encountered were mostly based on family and entailing family issues, conditions in rural areas, students' readiness level, difficulties in communication, lack of content, timing, classroom designs, and the management of many educational activities (Kutanoğlu, 2014). These obstacles particularly overlap with the current study's educational obstacles to cultivating a culture of creativity in social studies education, such as low-quality curriculum and instruction, teachers' negative perception of promoting creativity and lack of teachers' flexibility, freedom, and well-qualified teacher professional development.

Teachers from the current study defined encouraging students to express themselves in a freely, preventing from discouraging their solutions, ideas, studies. They also pointed out a classroom which is promoted students for freedom and nurtured with different educational tools and materials. These findings have similarities with Kutanoğlu's (2014) research. It is inferred that creative teacher behaviors may be defined in the inspiration of these findings in elementary social studies education. The further point is related to parental involvement for the creativity. Parent-school partnerships for educational activities may be a practical approach to keep students' 
creativity and imaginary refresh and sustainable inferred from the current study. Depending on curriculum guidance for teachers may be a challenge to foster creativity regarding teachers' implications. The positive attitudes and support of parents have a high impact on children's academic success and the other learning outcomes. However, families and the school should cooperate and act in coordination social studies based parental involvement activities (Kutanoğlu, 2014; Uğraş, 2011).

Several teachers from the current study pointed out differentiated teaching-learning activities, strategies, teaching techniques were significant components to plan educational process regarding promoting creativity. Activites based on inquiring and accessing knowledge support creative thinking (Kutanoğlu, 2014). The verbal lecture has been commonly used traditional teaching method in social studies education. However, question and answer teaching method, brainstorming and reverse brainstorming, problem-solving, discussion, project-based learning, acrostics, role-play, analogy are stated to foster students creative thinking and scaffold knowledge in social studies education (Vural, 2008). Implementation of drama and group studies have a positive influence on the critical and creative thinking skills and they also increase the outcomes of learning objectives. It has been pointed out that they will ensure that these learning attainments are permanent in the context of Turkish social studies education (Uğraş, 2011).

Citizenship skills may be nurtured with the creative thinking process. As teachers stated, cases and life events may be integrated to initiate creative thinking in the classroom. Social conflict prepare child expected social and environmental cases to be innovative in the process when they are adults, in other words, active citizens. Taylor, Brunvand, \& Iroha, (2015) similarly pointed out creative projects with real-world applications are motivational, and they promote civic education. The implementation of projects about democratic education and service learning, the integration of arts to the social studies, and encouraging of authentic assessments in contextual, culturally responsive teaching could be promoted(Taylor, Brunvand, \& Iroha, 2015).

Young children love to move, so making an opportunity for existing creative movement provides children learn about and explore the world easier than expected. Children use their bodies in a variety of activities through block play, art, dramatic play, dance and sports (e.g., running, climb, throw, and catch the wall, ride a tricycle or scooter). In the inspiration of teachers' views in the current study, learning environment and physical movement are important factors. For instance, including well-constructed planning, field trips (selecting an appropriate trip, curricular considerations for field trips) and cooking for social studies (benefits of cooking, some cautions when cooking with children, making picture recipes and safety in the school kitchen) may be implemented (Wallace, 2005). Besides, early childhood classrooms have art, music, and drama centers which is to support the children's developmental skills and creativity through rich experiences. (Melendez, Beck, \& Fletcher, 2000). Centers may be easily adapted to elementary classrooms to reveal out creative inspiration and imaginary in the context of social studies.

The teacher has an important role in scaffolding students' creative behaviors in the social studies classes. If the teacher takes the initiative to be more creative and have creative behaviors, effective teaching-learning environment, and better creative outcomes and learning outcomes for social studies come up in the process as elementary school teachers pointed in this study. Craft \& Jeffrey (2004) highlighted the relationship between teaching creatively and teaching for creativity. They found that teaching creatively and teaching for creativity depend on the situation. More specifically, teaching for creativity may well occur spontaneously in unintended situations. For example, students tend to model themselves after their teacher's approach in situations where they can take ownership and more likely be innovative, even if the teacher did not explicitly teach for creativity. These aspects may underpin many teachers' creative practices and pedagogical approaches (Craft \& Jeffrey, 2004, 2008). In sum, if creativity is used effectively, then it can enhance students' motivation to learn. To achieve this goal, teachers' behaviors and classrooms need to be organized with this objective in mind. As Zineddine (2010) stated, without focusing on this purpose, teachers will continue to face difficulties in motivating students to do their best work.

\section{Implications of the Present Study}

Promoting creativity is a critical feature in the relationship between teachers and students. This fact is, of course, in addition to high expectations, mutual respect, creative attitudes, flexibility, and discussions (Davies et al., 2013). Thus, project-based implications on creativity and innovation may be essential to promote teachers' creativity, while scaffolding different thinking skills in creative ways. When developing creativity, it is possible to develop different types of creativity, ranging from minor replications to major redirections in thinking (Sternberg, 2006). Projects can also provide rich inspiration, foster creative skills, and increase teachers' ability to foster creative learning (Craft, 2014). For example, the Creative Reversal Act (CREACT) has been an 
effective tool for promoting teachers' creative implementations (Sternberg, 2006) in a classroom context. Hence, it is recommended that teachers and trainers apply this tool in their respective teaching environments (Akar\& Şengil-Akar, 2013; İnel-Ekici, 2016; Sak \& Oz, 2010). In turn, these creative behaviors more likely to enact and inspire more constructive teaching and learning practices (Kwek, 2011).

Another implication of these findings is about developing of the creative potential of teachers. It is a key and main component of successful teaching and sustainable professional development. The creative potential of teachers also enhances their motivation to master common psychological and pedagogical knowledge, in-depth study of the teaching subject and competent teacher interaction with students (Berikkhanovaa, Zhussupovab, \& Berikkhanovac, 2015). Teacher professional development programs enrich teachers' interpretation and promotion of creativity. For example, Shen's research (2014), may have a good perspective to promote mathematical creativity by becoming deeper teachers' understanding of the nature of mathematics and supporting teachers based on grounded theory.

\section{Limitations and Conclusions}

The study has some limitations. Elementary school teachers in this study represent a specific sample of teachers who have volunteered to participate so, one should be cautious and limited when applying the findings to teachers in general. The data in this study was collected at one time in a qualitative strand; future studies should conduct a longitudinal study to investigate the possible changes in this particular context integrating quantitative strand of research. Also, there was a low diversity among participants regarding teachers' demographics and characteristics. Most participants were from the central region of Turkey. Thus results may not be representative of all teachers and parents from the social studies education across Turkey.

The findings from the current study point out perceptions and understanding and exploring of Turkish elementary school teachers of the creativity based on teachers' opinions and interpretations in the social studies education. Creativity is a broad and comprehensive concept and needs to be an ongoing process to adapt its implementations for practice to the classroom environments in the context of social studies education. In the current study, teachers thought, they could promote creativity to increase students' better social studies outcomes. Also, they had knowledge how to teach creatively in their practices, but they explained some particular deficiencies and inadequate in the educational process.

\section{References}

Akar, İ., \& Şengil-Akar, Ş. (2013). The Effectiveness of the Creative Reversal Act on Students' Creative Thinking: Further Evidence from Turkey. TOJET: The Turkish Online Journal of Educational Technology, 12(4), 183-191.

Bal, B. (2014). Türkçe dersi öğretim programlarinda yaratici düşünme [Creative thinking in teaching Turkish course curriculum]. Turkish Studies, 9, 247-257.

Berikkhanovaa, A. E., Zhussupovab, Z. A., \& Berikkhanovac, G. Y. (2015). Developing creative potential of future teachers: research and results. Procedia-Social and Behavioral Sciences, 171, 1142-1146. https://doi.org/10.1016/j.sbspro.2015.01.222

Chien, C., \& Hui, A. N. N. (2010). Creativity in early childhood education: Teachers' perceptions in three Chinese societies. Thinking Skills and Creativity, 5(2), 49-60. http://doi.org/10.1016/j.tsc.2010.02.002

Craft, A. (2003). The limits to creativity in education: Dilemmas for the educator. British Journal of Educational Studies, 51, 113-127. https://doi.org/10.1111/1467-8527.t01-1-00229

Craft, A. (2014). Fostering Possibility Through Co-Researching Creative Movement With 7-11 Year-Olds. Education, (January 2009).

Craft, A., \& Jeffrey, B. (2004). Learner inclusiveness for creative learning. Education 3-13, 32(2), 39-43. http://doi.org/10.1080/03004270485200201

Craft, A., \& Jeffrey, B. (2008). Creativity and performativity in teaching and learning: tensions, dilemmas, constraints, accommodations and synthesis. British Educational Research Journal, 34(5), 577-584. http://doi.org/10.1080/01411920802223842

Creswell, J. W. (2015). Educational research: Planning, conducting, and evaluating quantitative and qualitative research (5th edition). Boston, MA: Pearson.

Davies, D., Jindal-Snape, D., Collier, C., Digby, R., Hay, P., \& Howe, A. (2013). Creative learning environments in education-A systematic literature review. Thinking Skills and Creativity, 8(1), 80-91. 
http://doi.org/10.1016/j.tsc.2012.07.004

Faulkner, D., Coates, E., Craft, A., \& Duffy, B. (2006). Creativity and cultural innovation in early childhood education. International Journal of Early Years Education, 14(3), 191-199. http://doi.org/10.1080/09669760600879839

Gralewski, J. (2016). Teachers' beliefs about creativity and possibilities for its development in polish high schools: A qualitative study. DeGRuyter, 37, 3(2), 292-329. https://doi.org/10.1515/ctra-2016-0019

Gralewski, J., \& Karwowski, M. (2016). Are Teachers' Implicit Theories of Creativity Related to the Recognition of Their Students' Creativity?. Journal of Creative Behavior, 37. $\mathrm{http}: / /$ doi.org/10.1002/jocb.140

İnel-Ekici, D. (2016). How teachers evaluate themselves regarding their behaviours fostering students' creative thinking in learning environment?. International Periodical for the Languages, Literature and History of Turkish or Turkic, 11(3), 1287-1308. http://doi.org/http://dx.doi.org/10.7827/TurkishStudies.9292

Jones, R., \& Dennis, J. (2004). Humanities. In R. Jones \& D. Wyse (Eds.), Creativity in the primary curriculum (pp. 82-96). Great Britain: David Fulton Publishers.

Kabapınar, Y. (2007). İlköğretimde Hayat Bilgisi ve sosyal bilgiler öğretimi (1.Bsk). [Teaching life science and social studies in elementary education]. Ankara: Maya Akademi.

Kampylis, P., \& Berki, E. (2014). Nurturing Creative Thinking. Belle France: UNESCO. Retrieved from https://www.researchgate.net/publication/262242263_Nurturing_Creative_Thinking

Kirkendall, A., \& Krishen, A. S. (2016). Encouraging Creativity in the Social Work Classroom: Insights from a Qualitative Exploration, 5479(March). Retrieved from http://doi.org/10.1080/02615479.2014.986089

Kostelnik, M. J., Soderman, A. K., \& Whiren, A. P. (2011). Developmentally appropriate curriculum (5th edition). USA: Pearson.

Kutanoğlu, D. (2014). Hayat bilgisi dersindeki kazanımların öğrencilerin yaratıcı düşünme becerilerine katkısına yönelik ögrretmen görüslerinin ve uygulamalarının incelenmesi [The analysis of teacher remarks and implementations related to the contribution of attainments in social studies lesson to students' creative thinking ability](Unpublished Master's thesis). Northern Technical University, Trabzon, Turkey.

Kwek, P. G. H. (2011). Innovation in the Classroom: Design Thinking for 21st Century Learning. (Master's thesis). Retrieved from http://www.stanford.edu/group/redlab/cgibin/publications_resourcepg.php

Lackaff, J., \& Mindes, G. (2013). V. Social studies background and criteria. Social Studies Research Summary for The Work Sampling System (5th edition). Retrieved from https://iagepg.pearsonclinical.com/images/Assets/WSS_5/Research_Summary_Social_Studies_FNL.pdf

Loveless, A. (2015). Thinking about creativity: developing ideas, making things happen. In A. Wilson (Ed.), Creativity in primary education (3rd edition, pp. 129-143). Great Britain: Learning Matterpg. https://doi.org/10.4135/9781473909403.n11

Maxim, G. W. (1999). Dynamic social studies for elementary classrooms (7th edition). USA: Pearson Education.

Mayesky, M. (2009). Creative social studies. In Creative activities for young children. USA: Delmar Cengage Learning.

Melendez, W. R., Beck, V., \& Fletcher, M. (2000). Teaching social studies in early education. USA: Delmar Thomson Learning.

Merriam, P. G. B. (2009). Qualitative research: A guide to design and implementation. San Francisco, CA: John Wiley and Sons.

Mindes, G. (2008). Teaching young children social studies. UK: Rowman \& Littlefield Education.

Ministry of National Education (MONE). (2017a). Social studies curriculum guide from Grade 1 to Grade 3. Ankara: Devlet Kitapları Müdürlügü Basımevi.

Ministry of National Education (MONE). (2017b). Social studies curriculum guide Grade 4. Ankara: Devlet Kitapları Müdürlügü Basımevi.

Parker, W. C. (2012). Social studies in elementary education. Boston: Pearson Education Inc.

Sak, U., \& Oz, O. (2009). The effectiveness of the Creative Reversal Act (CREACT) on students' creative thinking. Thinking Skills and Creativity, 5, 33-39. https://doi.org/10.1016/j.tsc.2009.09.004 
Shen, Y. (2014). Elementary school teachers' interpretation and promotion of creativity in the learning of mathematics: A grounded theory study. Open Access Theses and Dissertations from the College of Education and Human Sciences. Paper 202. Retrieved from http://digitalcommonpg.unl.edu/cehsdiss/202

Tay, B., \& Baş, M. (2015). 2009 ve 2015 yılı hayat bilgisi dersi öğretim programlarının karşılaştırılması [Comparison of 2009 and 2015 Life Science Course curricula]. Bayburt Üniversitesi Eğitim Fakültesi Dergisi, 10(2), 345-346.

Taylor, J. A., Brunvand, P. G., \& Iroha, O. (2015). Portraiture in the social studies: Interdisciplinary and technological approaches to instruction. International Journal of Academic Research in Education, 1(2), 1-25. https://doi.org/10.17985/ijare.95924

Uçuş Güldalı, Ş., \& Demirbaş, İ. (2017). Comparison of life science curricula developed in 2009, 2015, 2017 regarding creative thinking, International Journal of Eurasia Social Sciences, 8(29), 969-990.

Ucus, S., \& Acar, I. H. (2017): Exploring the perceptions of student teachers about "creative school" in early childhood education. Early Child Development and Care. https://doi.org/10.1080/03004430.2017.1307838

Uçuş, Ş., Demirbaş, İ., Gafa, İ., Ylıdız, Z., \& Sönmez, K. (2017). Review of the eligibility of children’s books to the congruity of the social studies curricula (K1-K3). International Journal of Eurasia Social Sciences, $8(27), 408-441$.

Uğraş, H. (2011).Öğrencilerin hayat bilgisi dersinde eleştirel ve yaratici düşünme becerilerini kazanma düzeylerine ilişskin öğretmen görüssleri (Elazığ İli örneği) [Teacher' views about the levels of fulfillment of learning attainment on the critical and creative skillson life science lesson] (Unpublished Master's thesis). Firat University, Elazığ, Turkey.

Vural, C. T. (2008). Sosyal bilgiler eğitiminde yaratıcı düşünme: yeni ilköğretim programi beşinci sinif sosyal bilgiler öğretiminde kullanilan etkinliklerin yaraticiliği geliş̧tirmesi açisindan değerlendirilmesi [Creative thinking in education of social knowledge: evaluation of enhancing uses of activities creativity for newelemantary curriculum of fifth class social knowledge education] (Unpublished Master's thesis). Cukurova University, Adana, Turkey.

Wallace, M. C. (2005). Social studies-all day, every day in the early childhood classroom. USA: Thomson Delmar Learning.

Woolley, R., \& Claire, H. (2015). What has creativity got to do with citizenship education?. In A. Wilson (Ed.), Creativity in primary education (3rd edition, pp. 160-174). Great Britain: Learning Matte. https://doi.org/10.4135/9781473909403.n13

Y1ldırım, A. (2010). Creativity in early childhood education program. Procedia-Social and Behavioral Sciences, 9, 1561-1565. http://doi.org/10.1016/j.sbspro.2010.12.365

Yıldırım, A., \& Şimşek, H. (2008). Nitel araştırma yöntemleri (7th edition) [Qualitative research methods]. Ankara: Seçkin Yayıncılık.

Zineddine, B. M. (2010). Creative teaching to increase students' learning and achievement the case of English teachers. [Master's thesis]. Algeria: University of Constantine.

\section{Copyrights}

Copyright for this article is retained by the author(s), with first publication rights granted to the journal.

This is an open-access article distributed under the terms and conditions of the Creative Commons Attribution license (http://creativecommons.org/licenses/by/4.0/). 